90

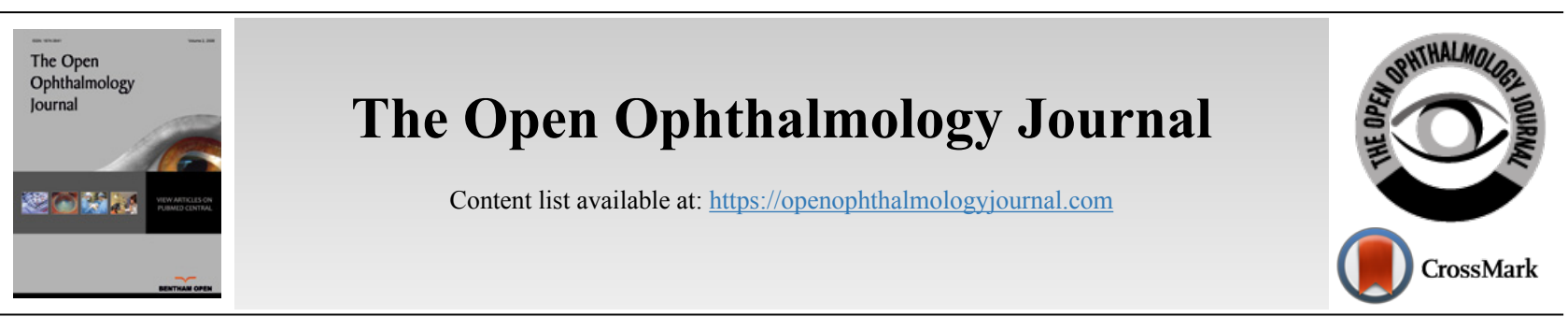

REVIEW ARTICLE

\title{
Age-related Macular Degeneration (AMD): A Review on its Epidemiology and Risk Factors
}

\author{
Nasim Salimiaghdam ${ }^{1, \#}$, Mohammad Riazi-Esfahani ${ }^{1}$, Paula S. Fukuhara ${ }^{1}$, Kevin Schneider ${ }^{1}$ and M. Cristina Kenney ${ }^{*}, 1,2$ \\ ${ }^{\prime}$ Gavin Herbert Eye Institute, Department of Ophthalmology, University of California Irvine, Irvine,92697, California, USA \\ ${ }^{2}$ Department of Pathology and Laboratory Medicine, University of California Irvine, Irvine, 92697, California, USA
}

\begin{abstract}
:
Age-related Macular Degeneration (AMD) is a type of maculopathy that results in irreversible visual impairment among the aged population in developed countries. The early stages of AMD can be diagnosed by the presence of drusen beneath the retinal pigment epithelial (RPE) cells. The advanced stages of AMD are geographical atrophy (dry type) and neovascular AMD (wet type), which lead to progressive and severe vision loss. The advanced stage of dry AMD can be identified by extensive large drusen, detachment of the RPE layer and finally degeneration of photoreceptors leading to central vision loss. The late stage of wet AMD is diagnosed by the presence of Choroidal Neovascularization (CNV) identified by Optical Coherence Tomography (OCT) or retinal angiography. The principal of AMD management is to impede the progression of early AMD to advanced levels. Patients with CNV are treated with anti-VEGF (Vascular Endothelial Growth Factor) compounds to inhibit blood vessel growth and thereby reducing vision loss. Although preventive methods for dry AMD are under investigation, there are no proven effective treatments.

A variety of environmental and genetic related risk factors are associated with increased incidence and progression of AMD. The genetic factors are found in the complement, angiogenic and lipid pathways. However, environmental factors, such as smoking and nutrition, are also major risk factors. Smoking is a modifiable environmental risk factor, which greatly increases the incidence and progress of AMD compared to non-smokers. There is growing evidence for the positive influence of a healthy diet containing high levels of anti-oxidant supplements. The reduction of serum lipids is another effective strategy for prevention AMD. Although no single preventive approach has been identified, knowing the high risk factors of AMD, along with modification of lifestyle is important for this multifactorial disease, especially in populations with higher genetic susceptibility. Though recent progress in early diagnosis of the disease has facilitated early and efficient intervention, further studies are required to gain more clarification of specific pathophysiology.

In spite of decades of focused research on AMD, the pathogenesis of AMD is still not completely understood. Recently, numerous novel methods, including imaging techniques, new drug delivery routes, and therapeutic strategies, are improving the management of AMD. In this review, we discuss the current knowledge related to epidemiology and classifications of AMD.
\end{abstract}

Keywords: Age-related Macular Degeneration (AMD), Definition, Epidemiology, Risk factors, OCT, CNV.

Article History

Received: August 11, 2019

Revised: November 18, 2019

Accepted: November 22, 2019

\section{INTRODUCTION: DEFINITION, EPIDEMIOLOGY AND RISK FACTORS}

\subsection{Definition}

In developed countries, large proportions of the elderly population suffer from severe visual difficulties resulting from $\mathrm{AMD}$ and this trend is rising worldwide because of the growing number of older individuals [1]. Based on a previous study, more than 1.75 million people in the United States are

\footnotetext{
* Address correspondence to this author at the Gavin Herbert Eye Institute, University of California Irvine, Hewitt Hall, Room 2028, 843 Health Science Road, Irvine, CA 92697; Tel: (949) 824-7603; Fax: (949) 824-9626; E-mail:mkenney@hs.uci.edu
}

affected by AMD and it is estimated to reach almost 3 million by 2020 [2]. The early stages of AMD are identified by the presence of hallmarks known as drusen and depigmentation of the RPE cells. Various types of drusen are associated with different levels of risk for AMD (Table 1). AMD progression from early to intermediate and advanced level is due to increased numbers of drusen and degeneration of RPE cells leading to pigmentary changes and formation of abnormal new blood vessels, respectively (Table 2) [3, 4]. The different stages of AMD during disease progression from early to advanced levels are illustrated in Figs. (1-3). The advanced levels of AMD are categorized into two forms: non-neovascular (dry, non-exudative or geographical) and neovascular (wet or exudative) AMD (Table 2) [4]. In dry AMD, geographic 
atrophy occurs in the RPE, photoreceptors and choriocapillaris, causing diminished visual acuity as a consequence of gradual cellular loss. In wet-type AMD, choroidal neovascularization leads to subretinal leakage of blood, lipids, fluids, and formation of fibrous scars [5 - 10]. Three types of CNV can be differentiated in wet type AMD. Type $1 \mathrm{CNV}$, also known as occult CNV, is located in sub-RPE space (Fig. 4A-4G) and type $2 \mathrm{CNV}$, known as classic $\mathrm{CNV}$, is located in sub-retinal space (Fig. 5A). Additionally, type $3 \mathrm{CNV}$ is identified as a proliferation of intraretinal angiomatose [11] (Figs. 6A-6D). There are a variety of imaging techniques available for guiding physicians facilitating the diagnosis and evaluation of response to therapy in patients with AMD. The useful imaging techniques in this regard include Optical Coherence Tomography (OCT), Fluorescein Angiography (FA), fundus photography, Indocyanine Green Angiography (ICG) and fundus autofluorescence imaging. The selection of the imaging technique depends on the patients' clinical status [12]. Examples of multimodal imaging of different types of CNV in patients with exudative AMD are shown in Figs. (1-3). In spite of significant advancements associated with diagnostic and treatment methods of AMD, further investigations are needed to identify effective therapies for dry forms of AMD and reduce the injection frequency of anti-VEGF compounds for wet AMD.

\subsection{Epidemiology}

In recent decades, numerous studies have been conducted on the epidemiology of AMD. Congdon et al. have estimated that $54 \%$ of the older white population that was legally blind in the United States suffered from AMD [13]. In 2003, approximately 8 million individuals ages 55 or beyond were affected by intermediate or the late forms of AMD in the United States [14]. Similarly, in the United Kingdom, the visual loss of approximately $75 \%$ of persons over 85 years was attributed to AMD [15]. Epidemiological surveys among populations with diverse ethnicities represent varied prevalence of AMD. Friedman et al. demonstrated that while drusen have frequent incidence in both white and black elderly populations, whites are remarkably more susceptible to develop advanced AMD [16]. When comparing Asian and Caucasians individuals affected with wet AMD, Asians are much more likely to have Polypoidal Choroid Vasculopathy (PCV), a modified form of AMD compared to Caucasian patients [17]. Klein et al.

Table 1. Differential characteristics of various drusen in AMD.

\begin{tabular}{|c|c|c|c|c|c|c|}
\hline $\begin{array}{c}\text { Different types of } \\
\text { drusen }\end{array}$ & Sizes & Edges & Shape & Location & Risks related to AMD & References \\
\hline Soft & Large $(>125$ ìm) & $\begin{array}{c}\text { Distinct or } \\
\text { indistinct edge }\end{array}$ & Dome-shaped & Central retina & $\begin{array}{l}\text { Increases the risk of severe } \\
\text { AMD and RPE pigmentation }\end{array}$ & {$[84,85]$} \\
\hline Hard & Small $(<63$ ìm $)$ & Distinct edge & Round & $\begin{array}{l}\text { Throughout the } \\
\text { retina }\end{array}$ & $\begin{array}{l}\text { Increases risk of presentation } \\
\text { of soft drusen }\end{array}$ & {$[86]$} \\
\hline Cuticular drusen & $\begin{array}{c}\text { Small } \\
(25-75 \mathrm{im})\end{array}$ & $\begin{array}{l}\text { Uniformly sized, } \\
\text { "stars in the sky" } \\
\text { pattern }\end{array}$ & Triangular, saw tooth & Around fovea & Increases the risk of $\mathrm{CNV}$ & {$[86-88]$} \\
\hline $\begin{array}{c}\text { Reticular } \\
\text { pseudodrusen }\end{array}$ & $\begin{array}{c}\text { Large } \\
(100-250 \mathrm{ìm})\end{array}$ & $\begin{array}{l}\text { Irregular } \\
\text { borders }\end{array}$ & $\begin{array}{l}\text { Networks of oval or } \\
\text { round lesions }\end{array}$ & $\begin{array}{l}\text { Located on apical } \\
\text { surface of RPE }\end{array}$ & $\begin{array}{c}\text { Increases the risk of advanced } \\
\text { forms of AMD }\end{array}$ & [89-92] \\
\hline
\end{tabular}
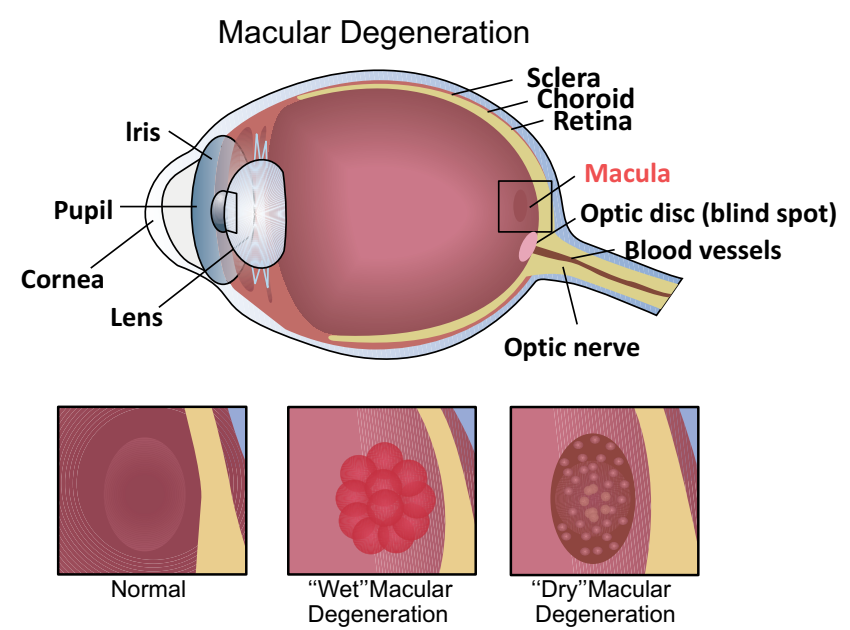

Fig. (1). Cross-sectional schematic of the total eye and macula in three different conditions (A) normal macula; (B) macula in exudative AMD with subretinal hemorrhage; (C) accumulation of drusen in macula in dry AMD. Taken with permission from www.shutterstock.com 
(A)

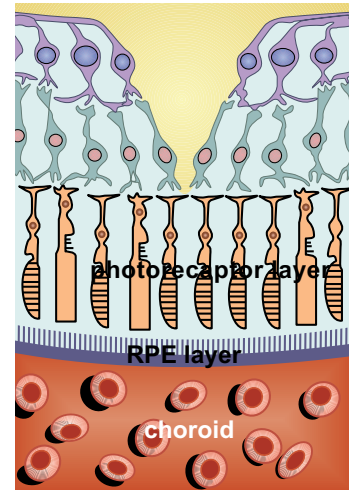

(B)

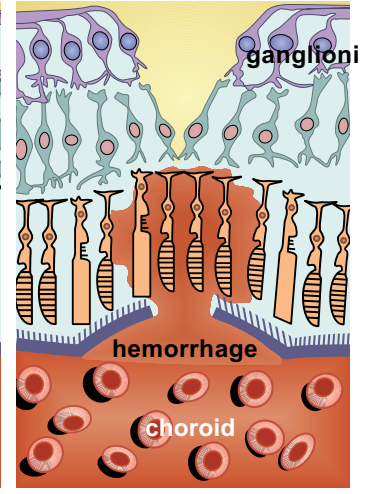

(C)

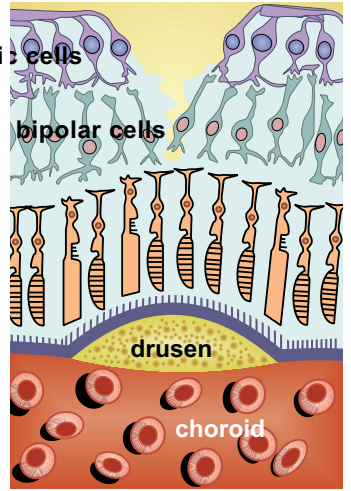

Fig. (2). Schematic of retina and choroid (A) normal retina; (B) new blood vessel formation and hemorrhage as a sign of wet AMD; (C) accumulation of drusen between Bruch's membrane and RPE layer as an early hallmark of dry AMD. Taken with permission from www.shutterstock.com.

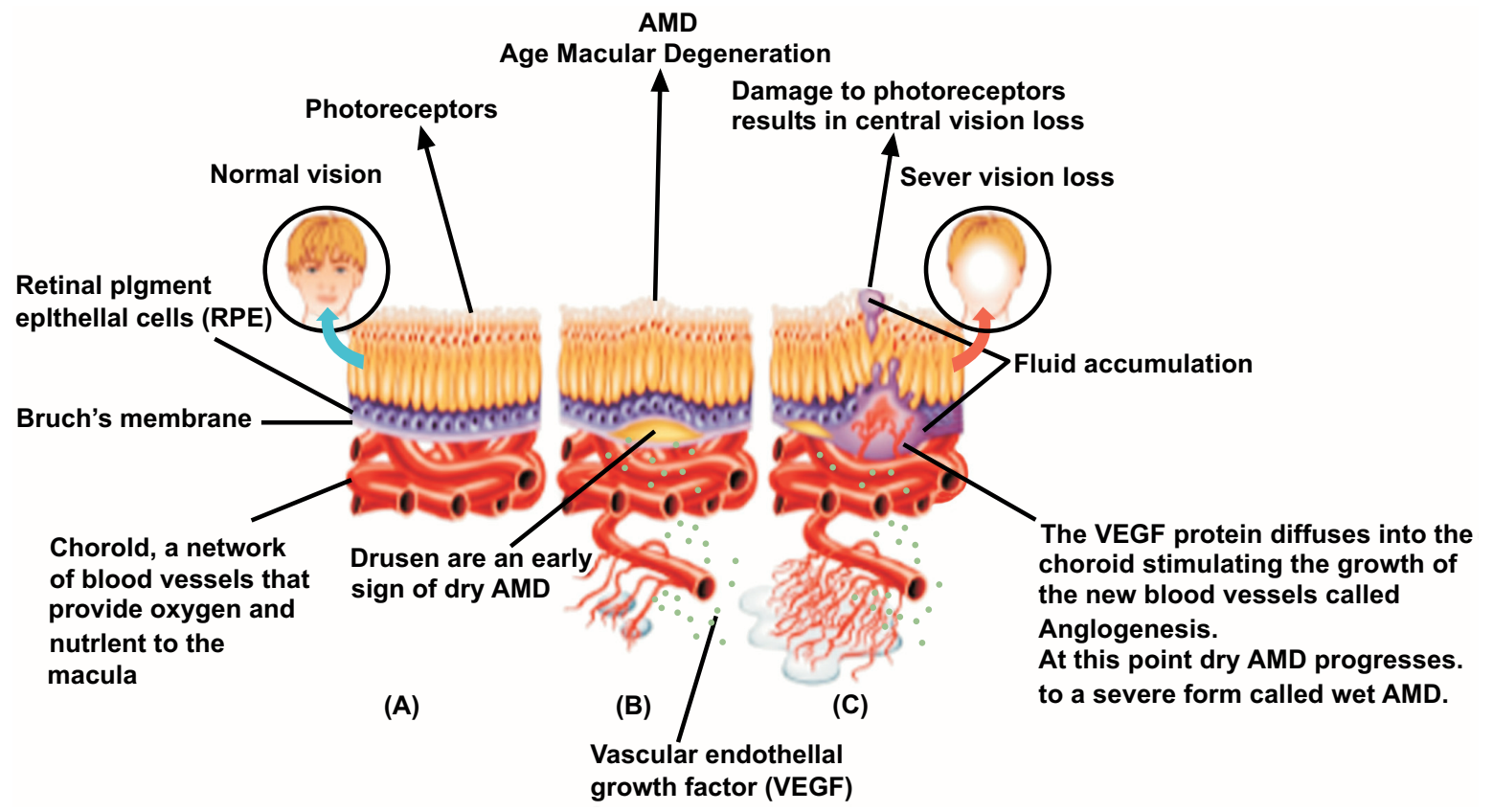

Fig. (3). Schematic of retina and choroid (A) normal retina with intact RPE layer; (B) presence of drusen between RPE layer and Bruch's membrane during dry AMD and inducement of production of VEGF; (C) formation of abnormal new blood vessels by VEGF in choroid (CNV), disturbance of integrity of Bruch's membrane and RPE layer leading to subretinal hemorrhage, fluid accumulation and finally visual impairment in advanced form of AMD. Taken with permission from www.dreamstime.com.

Table 2. Progression trend of AMD from early to advanced level [93 - 100].

\begin{tabular}{|c|c|c|c|c|}
\hline & Stage of AMD & Number and size of drusen & Other abnormalities & Management \\
\hline 1 & Normal aging & $\begin{array}{l}\text { No drusen or signs of few small }(<63 \mu \mathrm{m}) \text { sized drusen } \\
\text { in one/both eyes, or medium sized drusen in one eye }\end{array}$ & No signs of pigmentation & \\
\hline 2 & Early AMD & $\begin{array}{c}\text { Presence of few medium }(63-125 \mu \mathrm{m}) \text { sized drusen in } \\
\text { one or both eyes }\end{array}$ & Pigmentation & \multirow[t]{2}{*}{$\begin{array}{l}\text { Modification of } \\
\text { diet and lifestyle }\end{array}$} \\
\hline 3 & Intermediate & $\begin{array}{l}\text { Extensive medium drusen in both eyes or at least one } \\
\text { large drusen in one eye }\end{array}$ & $\begin{array}{l}\text { Geographical atrophy without } \\
\text { macular involvement }\end{array}$ & \\
\hline 4 & Advanced dry AMD & $\begin{array}{c}\text { Large drusen }(>125 \mu \mathrm{m}) \text { drusen or extensive medium in } \\
\text { both eyes }\end{array}$ & $\begin{array}{l}\text { Geographical atrophy extending to } \\
\text { macula }\end{array}$ & \begin{tabular}{|c|} 
Lifestyle management, \\
Anti-oxidant supplements \\
\end{tabular} \\
\hline 5 & \begin{tabular}{|c|}
$\begin{array}{c}\text { Advanced neovascular } \\
\text { AMD }\end{array}$ \\
\end{tabular} & $\begin{array}{c}\text { Extensive large drusen in the fovea in both eyes besides } \\
\text { hemorrhage and scars }\end{array}$ & $\begin{array}{c}\text { CNV, fluid leakage, RPE detachment, } \\
\text { Visual acuity less than } 20 / 32\end{array}$ & $\begin{array}{l}\text { Anti-VEGF therapy, laser } \\
\text { therapy }\end{array}$ \\
\hline
\end{tabular}


estimated that in the United States, the incidence of AMD in the elderly will rise significantly from $8 \%$ in 2005 to $54 \%$ in 2025 [1]. In this study, among participants between 43-54 years, the estimated rates for early and late AMD were 14.3\% and $3.1 \%$, respectively. However, the incidence rate of severe AMD reached $8 \%$ for persons over 75 years of age, making it a major problem affecting public health [1]. During a five-year study in Australia, the incidences of early AMD among people younger than 60 years and more than 80 years were estimated to be $13 \%$ and $20 \%$, respectively [18]. Smith and colleagues investigated three groups of racially identical participants from Australia, North America, and Europe. While AMD was seen in only a small proportion $(0.2 \%)$ of people between $55-64$ years of age, its prevalence increased to more than $13 \%$ of individuals over 85 years, without significant gender differences [19].

\subsection{Risk Factors}

Aging is the most consistent non-modifiable environmental risk factors for AMD [20, 21]. Besides aging, ethnicity and gender are also significant non-modifiable risk factors. There are no significant differences in frequencies of drusen between white and non-white populations. However, it has been showed that white female individuals are more susceptible to develop severe, late forms of AMD compared to black individuals [19, 22 - 24]. Smoking, higher body mass index, cardiovascular disease, high fat diet with restricted anti-oxidant compounds (e.g. vitamin $\mathrm{A}$, vitamin $\mathrm{C}$, vitamin $\mathrm{E}$ and zinc oxide) and unhealthy lifestyle are environmental risk factors associated with AMD [25 - 28].

Previous studies have shown that smoking, especially among women, significantly impacts the progression of AMD. The threat is the highest among active smokers but passive smokers are also affected negatively [19, 29 - 31]. The exact mechanism by which smoking impacts AMD is not clear. Some studies have shown that smoking causes a decline in serum antioxidant levels, potentially affecting the macula, which is highly sensitive to oxidative stress [32,33]. Moreover, other studies have validated smoking as a critical oxidative stressor that promotes the occurrence of AMD. The authors suggest that as a result of the oxidative stress generated by smoking, the mitochondrial DNA (mtDNA) become damaged, which induces RPE degradation and contributes to the formation of drusen [34 - 36]. In addition, smoking enhances atherosclerosis susceptibility that induces damage to choroidal vessels [37, 38]. Cardiovascular disease risk factors, such as hypertension and high serum cholesterol levels, are also associated with AMD [39 - 41]. Individuals with AMD are more predisposed to a range of cardiovascular diseases, including myocardial infarction [41, 42]. Previous studies emphasized for AMD patients the beneficial role of a healthy diet containing a larger proportion of fruits, vegetables and fish oil in contrast to diets of red meat, carbohydrates, oily and processed foods [43]. Husain et al. studied the association between AMD and serum lipid profile among 300 patients aged 50 years and beyond. The authors reported that the majority of 150 cases $(82.66 \%)$ had some form of dry AMD as compared to the $17.33 \%$ of cases with wet type AMD. Therefore, it was suggested that the serum lipid profile, particularly triglycerides (TG) and Very Low Density Lipoprotein (VLDL) are associated with increased risk of AMD [44]. Other studies have shown that due to limited production of estrogen during early menopause, females can be at greater risk to develop AMD $[45,46]$. In this regard, Snow and colleagues reported positive outcomes from exogenous estrogen therapy to diminish the risk of advanced AMD in post-menopausal patients [47].

Twin and familial aggregation/segregation studies have revealed that family history can be a risk factor in AMD [48 50]. There is a statistically higher concordance of AMD in monozygotic twins compared to dizygotic twins [51]. The risk of late AMD in siblings of parents with advanced AMD is approximately 4-fold higher compared to intermediate AMD. Also, first-degree relatives of those suffering from advanced AMD are more susceptible to developing Age-related Maculopathy (ARM) and may show earlier manifestations of AMD [52].

Several chromosomal loci associated with AMD have been identified. There are two major genetic regions contributing to AMD. The first identified susceptible gene for AMD was complement factor $\mathrm{H}(\mathrm{CFH})$, located on chromosome 1q31.3. The second major gene was LOC387715/HTRA1 located on 10q26 chromosome, which encodes a serine protease [53, 54]. Recently, Corominas and colleagues conducted a Whole Exome Sequencing (WES) study on 1361 control individuals and 1125 participants with AMD, which had European ancestry. Authors have identified that COL8A1 (collagen type VIII alpha 1 chain) gene located on 3 q12.1 chromosome is a component of Bruch's membrane, which is damaged in AMD. They revealed that in control participants, there were fewer alterations in that gene $(0.4 \%)$ compared to AMD patients $(1.0 \%)$. Therefore, it was suggested that the alteration of Bruch's membrane integrity by the COL $8 \mathrm{~A} 1$ gene contributes to the formation of drusen thereby playing a role in AMD development [55]. Additional genetic risk factors are Angiotensin-converting Enzyme (ACE), apolipoprotein E (APOE) and ATP-binding cassette rim (ABCA4) [56]. Allikmets et al. reported that changing the amino acids D2177N and G1961E on the ABCR (ABCA4) gene also has a significant association with AMD [57].

The $A P O E$ gene, a major regulator of lipids metabolism, is located on chromosome 19q13.2 [58]. Among three major alleles of APOE, the epsilon 2 allele of APOE gene has been shown to be a higher risk for AMD [59], whereas, APOE epsilon 4 allele has a protective effect for AMD [60,61]. Also, ACE (located on chromosome 17q23) with its Alu +/+ genotype has a protective role against AMD [62]. Other studies have demonstrated that the upregulation of $\mathrm{C} 2, \mathrm{C} 3, \mathrm{CBF}, \mathrm{CFI}$ genes in the complement pathway are negative influential factors for AMD [63 - 67].

There are also genes within specific biological pathways associated with AMD. For example, overexpression of genes encoding angiogenesis (VEGFA), extracellular collagen matrix (FRK/COL10A1), serum HDL (LIPC and CETP), and immune pathways (e.g. $\mathrm{CFH}, \mathrm{CFB}$ and $\mathrm{C} 3$ ) are negatively associated with early AMD and its progression to the advanced stage [63$65,68-70]$. Substantial distinctions of the dominance of risk 
alleles between geographical and neovascular AMD have not been demonstrated [71].

Recently, epigenetic modification of genes has gained considerable attention for associations with AMD. Stable epigenetic markers may be a link between environmental exposure and genetic alterations in AMD [72 - 76]. The epigenetic modifications, such as DNA methylation, acetylation and histones alterations may have protective or detrimental roles in AMD [77 - 81]. Udar and colleagues have reported specific single nucleotide polymorphism (SNP) variants in mitochondrial (mt) DNA of AMD patients compared to normal subjects and an increased association between AMD and individuals with the $\mathrm{U}, \mathrm{T}$ and $\mathrm{J}$ mtDNA haplogroups [82]. Also, in Austria, Mueller and colleagues analyzed mitochondrial haplogroups of 66 patients with dry AMD, 385 control participants and 200 persons suffering from exudative AMD. They reported that although haplogroup J was remarkably frequent in patients with neovascular AMD, the frequency of haplogroup $\mathrm{H}$ was considerably less in wet AMD subjects, demonstrating that the haplogroup $\mathrm{H}$ mtDNA has a protective role against AMD [83].

Future therapies for AMD may target genetic and epigenetic variations but additional studies are required to acquire full understanding at a molecular level how they are related to AMD pathogenesis.

OCT angiography image (Fig. 5A) shows type $2 \mathrm{CNV}$ in choroidal capillary layer (red arrow).

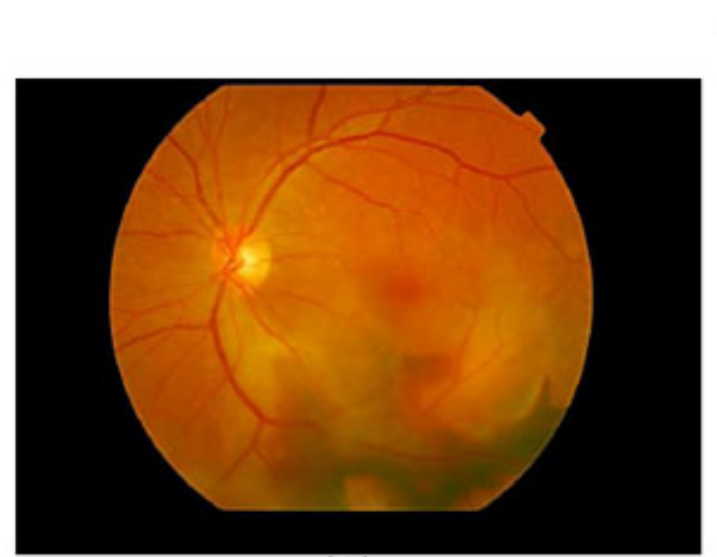

(A)

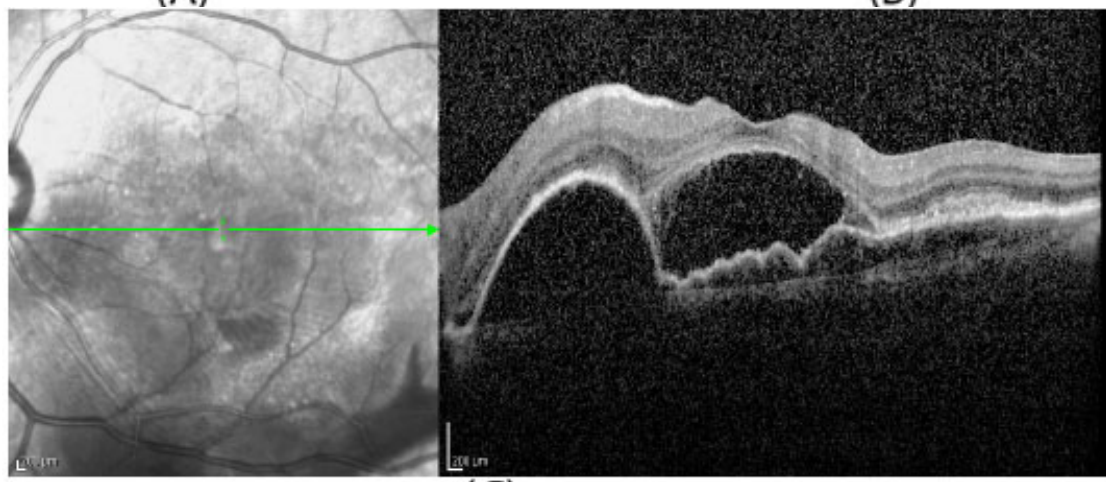

(C)

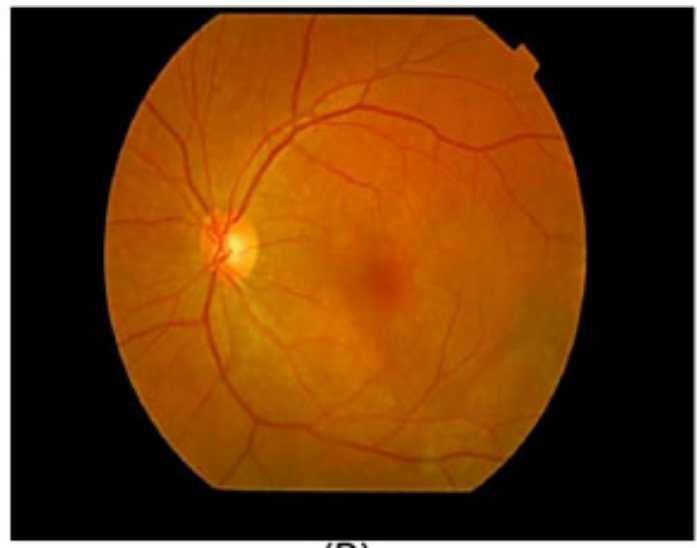

(B)

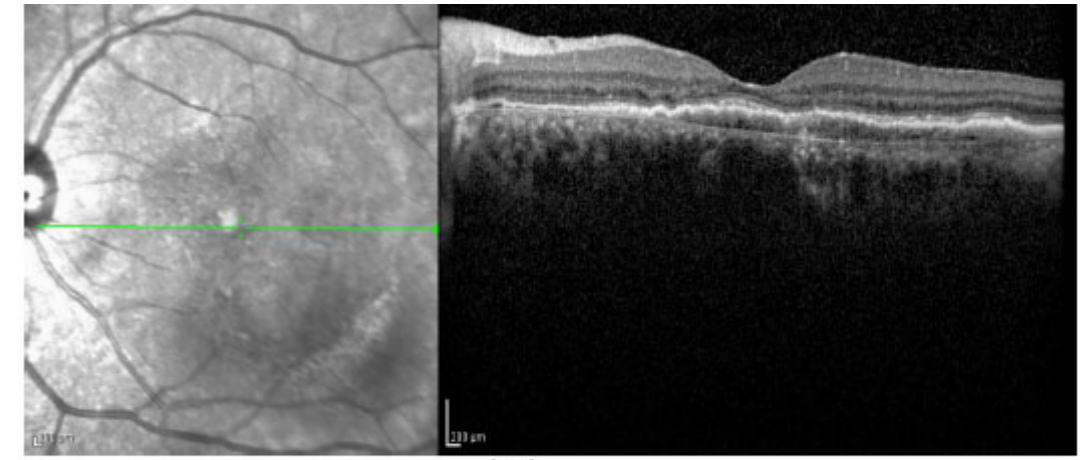

(D) 


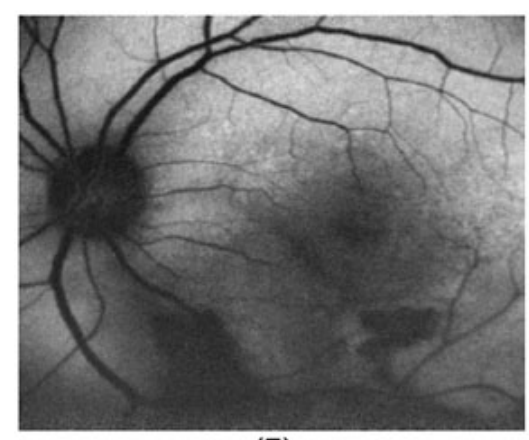

(E)

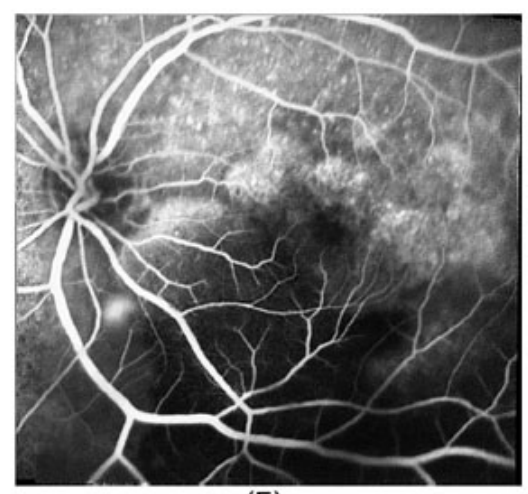

(F)

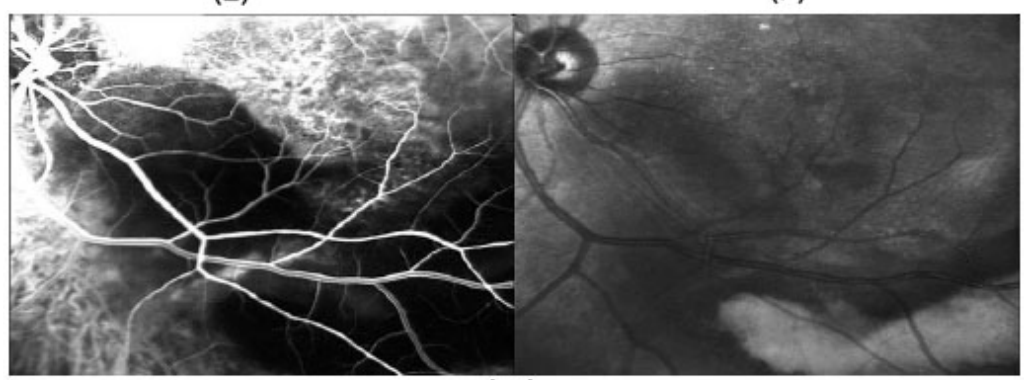

(G)

Fig. (4). Multimodal imaging of a patient with type $1 \mathrm{CNV}$. Fundus photography (Fig. 4A) shows the subretinal hemorrhage in the lower part of the macula. Fundus photography (Fig. 4B) of the same eye after treatment showing resolution of the subretinal hemorrhage (visual acuity 20/25). OCT image (Fig. 4C) shows subretinal fluid and pigment epithelial detachment with subretinal hyper-reflective material. OCT (Fig. 4D) of the same eye showing resorption of subretinal fluid and pigment epithelial detachment after treatment. Fundus autofluorescence before treatment (Fig. 4E) shows inferior hypoautofluorescence (corresponding to subretinal hemorrhage). Fluorescein angiography before treatment (Fig. 4F) with blockage of fluorescein in the area of subretinal hemorrhage with some superior hyperfluorescence. ICG angiography before treatment (Fig. 4G) shows hypercyanescence in a lacy pattern showing subretinal choroidal neovascularization and hypocyanescence in the area of thick subretinal hemorrhage.

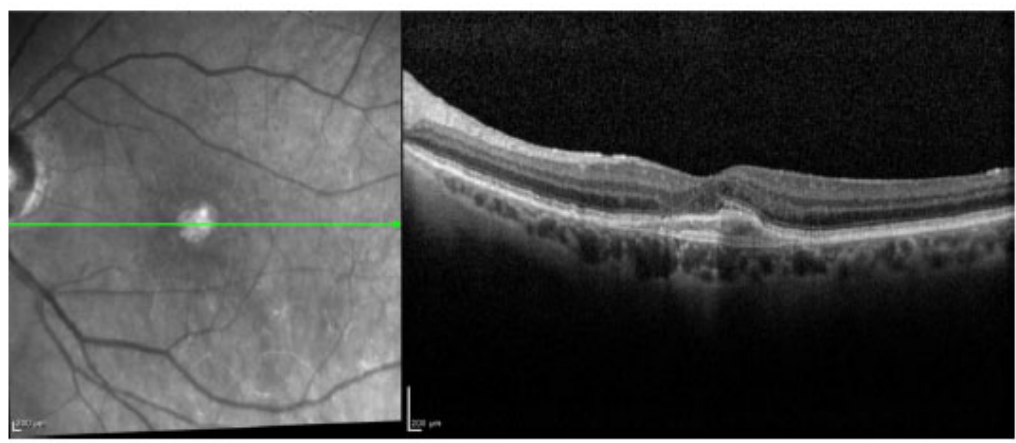

$(5 \mathrm{~A})$

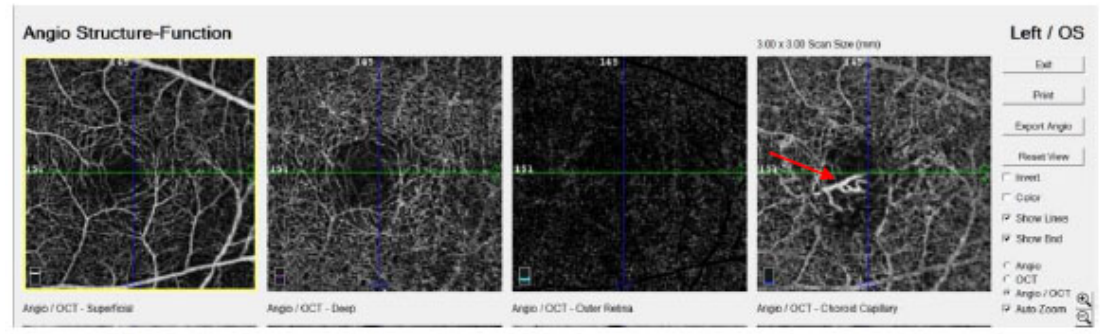

(5B)

Fig. (5). Multimodal imaging in a patient with type 2 CNV. OCT image (Fig. 5A) showing external limiting membrane (ELM) and ellipsoid zone (EZ) loss with subretinal hyper-reflective material. OCT angiography image (Fig. 5B) shows type $2 \mathrm{CNV}$ in choroidal capillary layer (red arrow). 


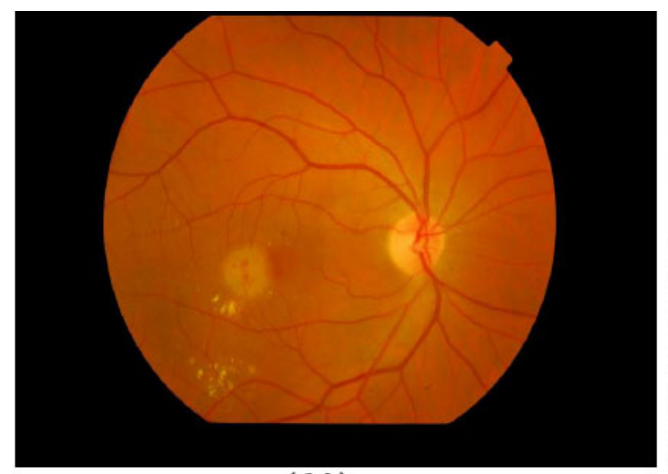

$(6 \mathrm{~A})$

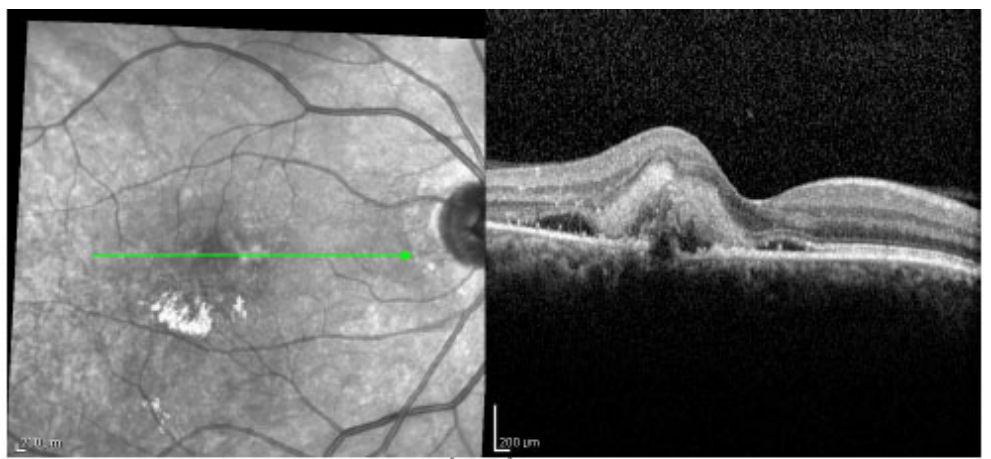

$(6 \bar{B})$

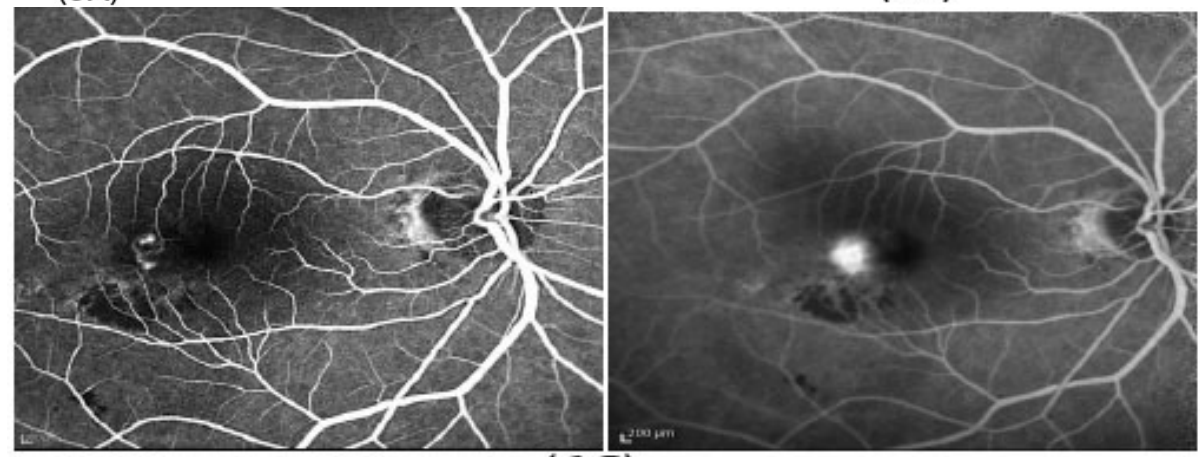

$(6 C)$

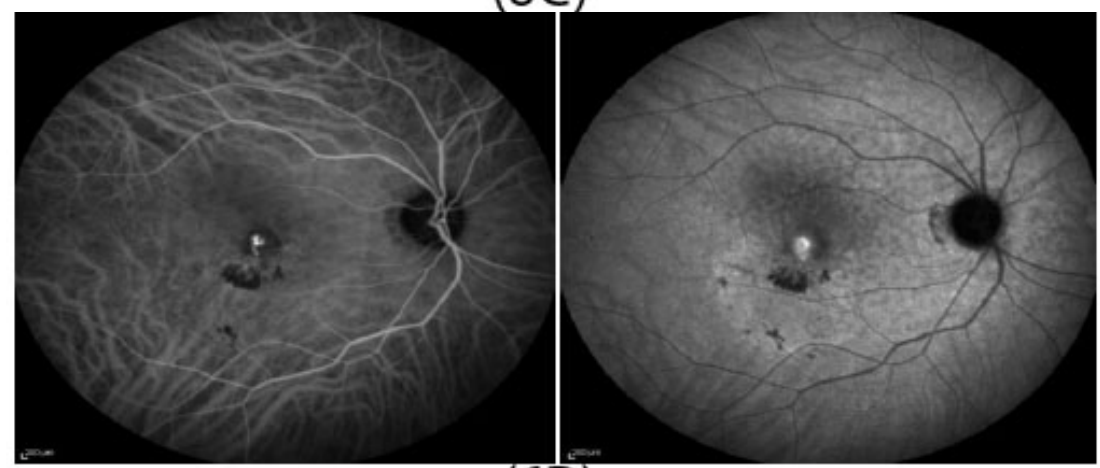

(6D)

Fig. (6). Multimodal imaging of type $3 \mathrm{CNV}$ in patients with wet AMD. Fundus photography (Fig. 6A) of the right macula shows small intraretinal hemorrhage temporal to the foveal center with hard exudate inferior to the hemorrhage. OCT image (Fig. 6B) shows retinal thickening with intraretinal and subretinal hyperreflective materials and subretinal fluid. Fluorescein angiography (Fig. 6C) shows leakage of the right-angle vessels, which are temporal to foveal center and the blockage of the choroidal flush inferior to the leakage. ICG angiography (Fig. 6D) shows hypercyanescence and late leakage from abnormal vessels.

\section{CONCLUSION}

Age-related macular degeneration negatively affects visual acuity in the elderly population. Although there is no single preventive method, alteration of modifiable risk factors can effectively impede the development of AMD. Both genetic and environmental risk factors are influential in the occurrence of AMD. Several major gene loci have been demonstrated as profoundly affecting the development of AMD. Modification of environmental risk factors, such as smoking and diet can play a preventive role in the progression of AMD. Recent progress in early diagnosis of the disease has facilitated early and efficient intervention. Anti-VEGF drugs have been influential agents for inhibition of $\mathrm{CNV}$ leading to the improvement of visual acuity. Nevertheless, these anti-VEGF agents have a high burden on patients because monthly injections are often required over extended periods of time. Fortunately, other new therapeutic approaches are being investigated, such as regenerative treatment options, which might yield better outcomes in the future. Further studies are required to gain more clarification of specific pathophysiology mechanisms that will allow us to develop novel preventive and therapeutic pathways in the future.

\section{CONSENT FOR PUBLICATION}

Not applicable.

\section{FUNDING}

Discovery Eye Foundation, Polly and Michael Smith, 
Edith and Roy Carver, Iris and B. Gerald Cantor Foundation, Unrestricted Departmental Grant from Research to Prevent Blindness and NEI R01 EY0127363 (MCK), Arnold and Mable Beckman Foundation and support of the Institute for Clinical and Transnational Science (ICTS) at University of California Irvine.

\section{CONFLICT OF INTEREST}

The authors declare no conflict of interest, financial or otherwise.

\section{ACKNOWLEDGEMENTS}

Declared none.

\section{REFERENCES}

[1] Klein R, Klein BE, Knudtson MD, Meuer SM, Swift M, Gangnon RE. Fifteen-year cumulative incidence of age-related macular degeneration: The Beaver Dam Eye Study. Ophthalmology 2007; 114(2): 253-62.

[http://dx.doi.org/10.1016/j.ophtha.2006.10.040] [PMID: 17270675]

[2] Owen CG, Fletcher AE, Donoghue M, Rudnicka AR. How big is the burden of visual loss caused by age related macular degeneration in the United Kingdom? Br J Ophthalmol 2003; 87(3): 312-7. [http://dx.doi.org/10.1136/bjo.87.3.312] [PMID: 12598445]

[3] Chakravarthy U, Evans J, Rosenfeld PJ. Age related macular degeneration. BMJ 2010; 340: c981.

[http://dx.doi.org/10.1136/bmj.c981] [PMID: 20189972]

[4] Jager RD, Mieler WF, Miller JW. Age-related macular degeneration. N Engl J Med 2008; 358(24): 2606-17. [http://dx.doi.org/10.1056/NEJMra0801537] [PMID: 18550876]

[5] Arya M, Sabrosa AS, Duker JS, Waheed NK. Choriocapillaris changes in dry age-related macular degeneration and geographic atrophy: A review. Eye Vis (Lond) 2018; 5(1): 22 [http://dx.doi.org/10.1186/s40662-018-0118-x] [PMID: 30238015]

[6] Heier JS, Brown DM, Chong V, et al. Intravitreal aflibercept (VEGF trap-eye) in wet age-related macular degeneration. Ophthalmology 2012; 119(12): 2537-48.

[http://dx.doi.org/10.1016/j.ophtha.2012.09.006] [PMID: 23084240]

[7] Brown DM, Kaiser PK, Michels M, et al. Ranibizumab versus verteporfin for neovascular age-related macular degeneration. N Engl J Med 2006; 355(14): 1432-44.

[http://dx.doi.org/10.1056/NEJMoa062655] [PMID: 17021319]

[8] Gragoudas ES, Adamis AP, Cunningham ET Jr, Feinsod M, Guyer DR. Pegaptanib for neovascular age-related macular degeneration. $\mathrm{N}$ Engl J Med 2004; 351(27): 2805-16. [http://dx.doi.org/10.1056/NEJMoa042760] [PMID: 15625332]

[9] Kuroda Y, Yamashiro K, Ooto S, et al. Macular atrophy and macular morphology in aflibercept-treated neovascular age-related macular degeneration. Retina 2018; 38(9): 1743-50.

[http://dx.doi.org/10.1097/IAE.0000000000001765] [PMID: 28691937]

[10] Rosenfeld PJ, Brown DM, Heier JS, et al. Ranibizumab for neovascular age-related macular degeneration. N Engl J Med 2006; 355(14): 1419-31.

[http://dx.doi.org/10.1056/NEJMoa054481] [PMID: 17021318]

[11] Farecki ML, Gutfleisch M, Faatz H, et al. Characteristics of type 1 and $2 \mathrm{CNV}$ in exudative AMD in OCT-Angiography. Graefes Arch Clin Exp Ophthalmol 2017; 255(5): 913-21.

[http://dx.doi.org/10.1007/s00417-017-3588-y] [PMID: 28233061]

[12] Freund KB, Toth C, Zarbin M. Best clinical practice for age-related macular degeneration imaging. J Vitreoretin Dis 2019; 3(3): 167-71. [http://dx.doi.org/10.1177/2474126419834702]

[13] Congdon N, et al. Causes and prevalence of visual impairment among adults in the United States. Arch Ophthalmol (Chicago, Ill.: 1960) 2004; 122: pp. (4)477-85.

[14] Bressler NM, et al. Potential public health impact of Age-related eye disease study results: AREDS report no 11. Arch Ophthalmol (Chicago, Ill.: 1960) 2003; 121: pp. (11)1621-4.

[15] Bunce C, Wormald R. Causes of blind certifications in England and Wales: April 1999-March 2000. Eye (Lond) 2008; 22(7): 905-11. [http://dx.doi.org/10.1038/sj.eye.6702767] [PMID: 17332762]
[16] Friedman DS, Katz J, Bressler NM, Rahmani B, Tielsch JM. Racial differences in the prevalence of age-related macular degeneration: The Baltimore Eye Survey. Ophthalmology 1999; 106(6): 1049-55. [http://dx.doi.org/10.1016/S0161-6420(99)90267-1] [PMID: 10366070]

[17] Laude A, Cackett PD, Vithana EN, et al. Polypoidal choroidal vasculopathy and neovascular age-related macular degeneration: Same or different disease? Prog Retin Eye Res 2010; 29(1): 19-29.

[http://dx.doi.org/10.1016/j.preteyeres.2009.10.001] [PMID: 19854291]

[18] Mukesh BN, Dimitrov PN, Leikin S, et al. Five-year incidence of agerelated maculopathy: The Visual Impairment Project. Ophthalmology 2004; 111(6): 1176-82.

[http://dx.doi.org/10.1016/j.ophtha.2003.08.042] [PMID: 15177968]

[19] Smith W, Assink J, Klein R, et al. Risk factors for age-related macular degeneration: Pooled findings from three continents. Ophthalmology 2001; 108(4): 697-704.

[http://dx.doi.org/10.1016/S0161-6420(00)00580-7] [PMID: 11297486]

[20] VanNewkirk MR, Nanjan MB, Wang JJ, Mitchell P, Taylor HR, McCarty CA. The prevalence of age-related maculopathy: The visual impairment project. Ophthalmology 2000; 107(8): 1593-600.

[http://dx.doi.org/10.1016/S0161-6420(00)00175-5] [PMID: 10919916]

[21] Klein R, Klein BE, Linton KL. Prevalence of age-related maculopathy. The Beaver Dam Eye Study. Ophthalmology 1992; 99(6): 933-43. [http://dx.doi.org/10.1016/S0161-6420(92)31871-8] [PMID: 1630784]

[22] Friedman DS, O'Colmain BJ, Muñoz B, et al. Prevalence of agerelated macular degeneration in the United States. Arch Ophthalmol 2004; 122(4): 564-72.

[http://dx.doi.org/10.1001/archopht.1941.00870100042005] [PMID: 15078675]

[23] Schachat AP, Hyman L, Leske MC, Connell AM, Wu SY. Features of age-related macular degeneration in a black population. Arch Ophthalmol 1995; 113(6): 728-35.

[http://dx.doi.org/10.1001/archopht.1995.01100060054032] [PMID: 7786213]

[24] Risk factors associated with age-related macular degeneration. A casecontrol study in the age-related eye disease study: Age-Related Eye Disease Study Report Number 3. Ophthalmology 2000; 107(12): 2224-32.

[PMID: 11097601]

[25] Seddon JM, Cote J, Davis N, Rosner B. Progression of age-related macular degeneration: Association with body mass index, waist circumference, and waist-hip ratio. Arch Ophthalmol 2003; 121(6): 785-92.

[http://dx.doi.org/10.1001/archopht.121.6.785] [PMID: 12796248]

[26] Seddon JM, Ajani UA, Sperduto RD, et al. Dietary carotenoids, vitamins $\mathrm{A}, \mathrm{C}$, and $\mathrm{E}$, and advanced age-related macular degeneration. JAMA 1994; 272(18): 1413-20.

[http://dx.doi.org/10.1001/jama.1994.03520180037032] [PMID: 7933422]

[27] Mares-Perlman JA, et al. Dietary fat and age-related maculopathyReply. Arch Ophthalmol 1996; 114(2): 236-6.

[http://dx.doi.org/10.1001/archopht.1996.01100130229032]

[28] Chakravarthy U, Wong TY, Fletcher A, et al. Clinical risk factors for age-related macular degeneration: A systematic review and metaanalysis. BMC Ophthalmol 2010; 10(1): 31

[http://dx.doi.org/10.1186/1471-2415-10-31] [PMID: 21144031]

[29] Seddon JM, Willett WC, Speizer FE, Hankinson SE. A prospective study of cigarette smoking and age-related macular degeneration in women. JAMA 1996; 276(14): 1141-6.

[http://dx.doi.org/10.1001/jama.1996.03540140029022] [PMID: 8827966]

[30] Delcourt C, et al. Smoking and age-related macular degeneration: the POLA Study. Arch Ophthalmol 116(8): 1031-5.

[http://dx.doi.org/10.1001/archopht.116.8.1031]

[31] Khan JC, Thurlby DA, Shahid H, et al. Smoking and age related macular degeneration: the number of pack years of cigarette smoking is a major determinant of risk for both geographic atrophy and choroidal neovascularisation. Br J Ophthalmol 2006; 90(1): 75-80. [http://dx.doi.org/10.1136/bjo.2005.073643] [PMID: 16361672]

[32] Stryker WS, Kaplan LA, Stein EA, Stampfer MJ, Sober A, Willett WC. The relation of diet, cigarette smoking, and alcohol consumption to plasma beta-carotene and alpha-tocopherol levels. Am J Epidemiol 1988; 127(2): 283-96.

[http://dx.doi.org/10.1093/oxfordjournals.aje.a114804] [PMID: 
3257350]

[33] Sanders TA, Haines AP, Wormald R, Wright LA, Obeid O. Essential fatty acids, plasma cholesterol, and fat-soluble vitamins in subjects with age-related maculopathy and matched control subjects. Am J Clin Nutr 1993; 57(3): 428-33

[http://dx.doi.org/10.1093/ajcn/57.3.428] [PMID: 8438779]

[34] Cano M, Thimmalappula R, Fujihara M, et al. Cigarette smoking, oxidative stress, the anti-oxidant response through Nrf2 signaling, and Age-related Macular Degeneration. Vision Res 2010; 50(7): 652-64. [http://dx.doi.org/10.1016/j.visres.2009.08.018] [PMID: 19703486]

[35] Wang AL, Lukas TJ, Yuan M, Du N, Handa JT, Neufeld AH. Changes in retinal pigment epithelium related to cigarette smoke: Possible relevance to smoking as a risk factor for age-related macular degeneration. PLoS One 2009; 4(4)e5304

[http://dx.doi.org/10.1371/journal.pone.0005304] [PMID: 19390692]

[36] Wang AL, Neufeld AH. Smoking mice: A potential model for studying accumulation of drusen-like material on Bruch's membrane. Vision Res 2010; 50(7): 638-42.

[http://dx.doi.org/10.1016/j.visres.2009.08.029] [PMID: 19765605]

[37] Parmley WW. Nonlipoprotein risk factors for coronary heart disease: Evaluation and management. Am J Med 1997; 102(2A): 7-14. [http://dx.doi.org/10.1016/S0002-9343(97)00461-0] [PMID: 9217580]

[38] Vingerling JR, Dielemans I, Bots ML, Hofman A, Grobbee DE, de Jong PT. Age-related macular degeneration is associated with atherosclerosis. The Rotterdam Study. Am J Epidemiol 1995; 142(4): 404-9.

[http://dx.doi.org/10.1093/oxfordjournals.aje.a117648] [PMID: 7625405]

[39] Hyman L, Schachat AP, He Q, Leske MC. Hypertension, cardiovascular disease, and age-related macular degeneration. Arch Ophthalmol 2000; 118(3): 351-8.

[http://dx.doi.org/10.1001/archopht.118.3.351] [PMID: 10721957]

[40] Reynolds R, Rosner B, Seddon JM. Serum lipid biomarkers and hepatic lipase gene associations with age-related macular degeneration. Ophthalmology 2010; 117(10): 1989-95.

[http://dx.doi.org/10.1016/j.ophtha.2010.07.009] [PMID: 20888482]

[41] Snow KK, Seddon JM. Do age-related macular degeneration and cardiovascular disease share common antecedents? Ophthalmic Epidemiol 1999; 6(2): 125-43.

[http://dx.doi.org/10.1076/opep.6.2.125.1558] [PMID: 10420212]

[42] Duan Y, Mo J, Klein R, et al. Age-related macular degeneration is associated with incident myocardial infarction among elderly Americans. Ophthalmology 2007; 114(4): 732-7.

[http://dx.doi.org/10.1016/j.ophtha.2006.07.045] [PMID: 17187863]

[43] de Koning-Backus AP, Kiefte-de Jong JC, Klaver CC. Dietary patterns and age-related macular degeneration, in handbook of nutrition, diet, and the eye. Sci Rep 2019; 9(1): 8200.

[PMID: 31160668]

[44] Husain A, et al. Study of association between the serum lipid profile and age-related macular degeneration in a tertiary care centre of Central UP. Int J Res Med 2019; 7(4): 1104.

[http://dx.doi.org/10.18203/2320-6012.ijrms20191307]

[45] Smith W, Mitchell P, Wang JJ. Gender, oestrogen, hormone replacement and age-related macular degeneration: Results from the Blue Mountains Eye Study. Aust N Z J Ophthalmol 1997; 25(4)(Suppl. 1): S13-5.

[http://dx.doi.org/10.1111/j.1442-9071.1997.tb01745.x] [PMID: 9267614]

[46] Snow KK, Seddon JM. Age-related eye diseases: Impact of hormone replacement therapy, and reproductive and other risk factors. Int J Fertil Womens Med 2000; 45(5): 301-13.

[PMID: 11092701]

[47] Snow KK, Cote J, Yang W, Davis NJ, Seddon JM. Association between reproductive and hormonal factors and age-related maculopathy in postmenopausal women. Am J Ophthalmol 2002; 134(6): 842-8.

[http://dx.doi.org/10.1016/S0002-9394(02)01755-5] [PMID: 12470752]

[48] Seddon JM, Ajani UA, Mitchell BD. Familial aggregation of agerelated maculopathy. Am J Ophthalmol 1997; 123(2): 199-206. [http://dx.doi.org/10.1016/S0002-9394(14)71036-0] [PMID: 9186125]

[49] Smith W, Mitchell P. Family history and age-related maculopathy: The Blue Mountains Eye Study. Aust N Z J Ophthalmol 1998; 26(3): 203-6.

[http://dx.doi.org/10.1111/j.1442-9071.1998.tb01311.x] [PMID: 9717749]

[50] Gottfredsdottir MS, Sverrisson T, Musch DC, Stefánsson E. Age related macular degeneration in monozygotic twins and their spouses in Iceland. Acta Ophthalmol Scand 1999; 77(4): 422-5.

[http://dx.doi.org/10.1034/j.1600-0420.1999.770413.x] [PMID: 10463414]

[51] Meyers SM, Greene T, Gutman FA. A twin study of age-related macular degeneration. Am J Ophthalmol 1995; 120(6): 757-66. [http://dx.doi.org/10.1016/S0002-9394(14)72729-1] [PMID: 8540549]

[52] Klaver CC, Wolfs RC, Assink JJ, van Duijn CM, Hofman A, de Jong PT. Genetic risk of age-related maculopathy. Population-based familial aggregation study. Arch Ophthalmol 1998; 116(12): 1646-51. [http://dx.doi.org/10.1001/archopht.116.12.1646] [PMID: 9869796]

[53] Scholl HP, Fleckenstein M, Charbel Issa P, Keilhauer C, Holz FG, Weber BH. An update on the genetics of age-related macular degeneration. Mol Vis 2007; 13: 196-205.

[http://dx.doi.org/10.1007/978-3-540-33672-3_3] [PMID: 17327825]

[54] Despriet DD, Klaver CC, Witteman JC, et al. Complement factor $\mathrm{H}$ polymorphism, complement activators, and risk of age-related macular degeneration. JAMA 2006; 296(3): 301-9.

[http://dx.doi.org/10.1001/jama.296.3.301] [PMID: 16849663]

[55] Corominas J, Colijn JM, Geerlings MJ, et al. Whole-exome sequencing in age-related macular degeneration identifies rare variants in col8a1, a component of bruch's membrane. Ophthalmology 2018; 125(9): 1433-43

[http://dx.doi.org/10.1016/j.ophtha.2018.03.040] [PMID: 29706360]

[56] Hamdi HK, Kenney C. Age-related macular degeneration: A new viewpoint. Front Biosci 2003; 8: e305-14.

[http://dx.doi.org/10.2741/1019] [PMID: 12700041]

[57] Allikmets R. Further evidence for an association of ABCR alleles with age-related macular degeneration. Am J Hum Genet 2000; 67(2): 487-91.

[http://dx.doi.org/10.1086/303018] [PMID: 10880298]

[58] Das HK, McPherson J, Bruns GA, Karathanasis SK, Breslow JL. Isolation, characterization, and mapping to chromosome 19 of the human apolipoprotein E gene. J Biol Chem 1985; 260(10): 6240-7. [PMID: 3922972]

[59] Klaver CC, Kliffen M, van Duijn CM, et al. Genetic association of apolipoprotein $\mathrm{E}$ with age-related macular degeneration. Am J Hum Genet 1998; 63(1): 200-6.

[http://dx.doi.org/10.1086/301901] [PMID: 9634502]

[60] Souied EH, Benlian P, Amouyel P, et al. The epsilon4 allele of the apolipoprotein $\mathrm{E}$ gene as a potential protective factor for exudative age-related macular degeneration. Am J Ophthalmol 1998; 125(3): 353-9.

[http://dx.doi.org/10.1016/S0002-9394(99)80146-9] [PMID: 9512153]

[61] Schmidt S, Saunders AM, Postel EA, et al. Association of the apolipoprotein E gene with age-related macular degeneration: Possible effect modification by family history, age, and gender. Mol Vis 2000; 6: 287-93.

[PMID: 11141572]

[62] Hamdi HK, Reznik J, Castellon R, et al. Alu DNA polymorphism in $\mathrm{ACE}$ gene is protective for age-related macular degeneration. Biochem Biophys Res Commun 2002; 295(3): 668-72. [http://dx.doi.org/10.1016/S0006-291X(02)00728-3] 12099691]

[63] Klein RJ, Zeiss C, Chew EY, et al. Complement factor H polymorphism in age-related macular degeneration. Science 2005; 308(5720): 385-9.

[http://dx.doi.org/10.1126/science.1109557] [PMID: 15761122]

[64] Maller JB, Fagerness JA, Reynolds RC, Neale BM, Daly MJ, Seddon JM. Variation in complement factor 3 is associated with risk of agerelated macular degeneration. Nat Genet 2007; 39(10): 1200-1. [http://dx.doi.org/10.1038/ng2131] [PMID: 17767156]

[65] Fagerness JA, Maller JB, Neale BM, Reynolds RC, Daly MJ, Seddon JM. Variation near complement factor I is associated with risk of advanced AMD. Eur J Hum Genet 2009; 17(1): 100-4. [http://dx.doi.org/10.1038/ejhg.2008.140] [PMID: 18685559]

[66] Gold B, Merriam JE, Zernant J, et al. Variation in factor B (BF) and complement component $2(\mathrm{C} 2)$ genes is associated with age-related macular degeneration. Nat Genet 2006; 38(4): 458-62.

[http://dx.doi.org/10.1038/ng1750] [PMID: 16518403]

[67] Yates JR, Sepp T, Matharu BK, et al. Complement C3 variant and the risk of age-related macular degeneration. N Engl J Med 2007; 357(6): 553-61.

[http://dx.doi.org/10.1056/NEJMoa072618] [PMID: 17634448]

[68] Seddon JM, Reynolds R, Yu Y, Daly MJ, Rosner B. Risk models for progression to advanced age-related macular degeneration using demographic, environmental, genetic, and ocular factors. 
Ophthalmology 2011; 118(11): 2203-11. [http://dx.doi.org/10.1016/j.ophtha.2011.04.029] [PMID: 21959373]

[69] Yu Y, Bhangale TR, Fagerness J, et al. Common variants near FRK/COL10A1 and VEGFA are associated with advanced age-related macular degeneration. Hum Mol Genet 2011; 20(18): 3699-709. [http://dx.doi.org/10.1093/hmg/ddr270] [PMID: 21665990]

[70] Ding X, Patel M, Chan CC. Molecular pathology of age-related macular degeneration. Prog Retin Eye Res 2009; 28(1): 1-18. [http://dx.doi.org/10.1016/j.preteyeres.2008.10.001] [PMID: 19026761]

[71] Yang Z, Camp NJ, Sun H, et al. A variant of the HTRA1 gene increases susceptibility to age-related macular degeneration. Science 2006; 314(5801): 992-3.

[http://dx.doi.org/10.1126/science.1133811] [PMID: 17053109]

[72] Skinner MK. Environmental epigenetic transgenerational inheritance and somatic epigenetic mitotic stability. Epigenetics 2011; 6(7): 838-42

[http://dx.doi.org/10.4161/epi.6.7.16537] [PMID: 21637037]

[73] Wei L, Chen P, Lee JH, Nussenblatt RB. Genetic and Epigenetic Regulation in Age-related Macular Degeneration. Asia Pac J Ophthalmol (Phila) 2013; 2(4): 269-74.

[http://dx.doi.org/10.1097/APO.0b013e31829e2793] [PMID: 23997991]

[74] Parmeggiani F, Sorrentino FS, Romano MR, et al. Mechanism of inflammation in age-related macular degeneration: An up-to-date on genetic landmarks. Mediators Inflamm 2013; 2013435607 [http://dx.doi.org/10.1155/2013/435607] [PMID: 24369445]

[75] Gemenetzi M, Lotery AJ. The role of epigenetics in age-related macular degeneration. Eye (Lond) 2014; 28(12): 1407-17. [http://dx.doi.org/10.1038/eye.2014.225] [PMID: 25233816]

[76] He S, Li X, Chan N, Hinton DR. Review: Epigenetic mechanisms in ocular disease. Mol Vis 2013; 19: 665-74. [PMID: 23559860]

[77] Kwa FA, Thrimawithana TR. Epigenetic modifications as potential therapeutic targets in age-related macular degeneration and diabetic retinopathy. Drug Discov Today 2014; 19(9): 1387-93. [http://dx.doi.org/10.1016/j.drudis.2014.03.026] [PMID: 24717156]

[78] Riazi-Esfahani M, Kuppermann BD, Kenney MC. The role of mitochondria in amd: Current knowledge and future applications. J Ophthalmic Vis Res 2017; 12(4): 424-8.

[http://dx.doi.org/10.4103/jovr.jovr_182_17] [PMID: 29090054]

[79] Atilano SR, Malik D, Chwa M, et al. Mitochondrial DNA variants can mediate methylation status of inflammation, angiogenesis and signaling genes. Hum Mol Genet 2015; 24(16): 4491-503. [http://dx.doi.org/10.1093/hmg/ddv173] [PMID: 25964427]

[80] Kenney MC, Chwa M, Atilano SR, et al. Mitochondrial DNA variants mediate energy production and expression levels for $\mathrm{CFH}, \mathrm{C} 3$ and EFEMP1 genes: Implications for age-related macular degeneration. PLoS One 2013; 8(1)e54339

[http://dx.doi.org/10.1371/journal.pone.0054339] [PMID: 23365660]

[81] Wallace DC. Mitochondrial DNA mutations in disease and aging. Environ Mol Mutagen 2010; 51(5): 440-50.

[http://dx.doi.org/10.1002/em.20586] [PMID: 20544884]

[82] Udar N, Atilano SR, Memarzadeh M, et al. Mitochondrial DNA haplogroups associated with age-related macular degeneration. Invest Ophthalmol Vis Sci 2009; 50(6): 2966-74.

[http://dx.doi.org/10.1167/iovs.08-2646] [PMID: 19151382]

[83] Mueller EE, Schaier E, Brunner SM, et al. Mitochondrial haplogroups and control region polymorphisms in age-related macular degeneration: a case-control study. PLoS One 2012; 7(2)e30874 [http://dx.doi.org/10.1371/journal.pone.0030874] [PMID: 22348027]

[84] Bressler NM, Bressler SB, Fine SL. Age-related macular degeneration. Surv Ophthalmol 1988; 32(6): 375-413.

[http://dx.doi.org/10.1016/0039-6257(88)90052-5] [PMID: 2457955]

[85] Bressler NM, Bressler SB, Seddon JM, Gragoudas ES, Jacobson LP. Drusen characteristics in patients with exudative versus non-exudative age-related macular degeneration. Retina 1988; 8(2): 109-14. [http://dx.doi.org/10.1097/00006982-198808020-00005] [PMID:
3420311]

[86] Nivison-Smith L, Milston R, Madigan M, Kalloniatis M. Age-related macular degeneration: linking clinical presentation to pathology. Optom Vis Sci 2014; 91(8): 832-48.

[http://dx.doi.org/10.1097/OPX.0000000000000281]

[PMID: 24879089]

[87] Spaide RF, Curcio CA. Drusen characterization with multimodal imaging. Retina 2010; 30(9): 1441-54.

[http://dx.doi.org/10.1097/IAE.0b013e3181ee5ce8]

[PMID: 20924263]

[88] Leng T, Rosenfeld PJ, Gregori G, Puliafito CA, Punjabi OS. Spectral domain optical coherence tomography characteristics of cuticular drusen. Retina 2009; 29(7): 988-93.

[http://dx.doi.org/10.1097/IAE.0b013e3181ae7113] [PMID: 19584657]

[89] Hogg RE. Reticular pseudodrusen in age-related macular degeneration. Optom Vis Sci 2014; 91(8): 854-9.

[http://dx.doi.org/10.1097/OPX.0000000000000287] 24950032]

[90] Hogg RE, Silva R, Staurenghi G, et al. Clinical characteristics of reticular pseudodrusen in the fellow eye of patients with unilateral neovascular age-related macular degeneration. Ophthalmology 2014; 121(9): 1748-55.

[http://dx.doi.org/10.1016/j.ophtha.2014.03.015] [PMID: 24856310]

[91] Lee MY, Yoon J, Ham D-I. Clinical characteristics of reticular pseudodrusen in Korean patients. Am J Ophthalmol 2012; 153(3): 530-5.

[http://dx.doi.org/10.1016/j.ajo.2011.08.012] [PMID: 21996310]

[92] Zweifel SA, Imamura Y, Spaide TC, Fujiwara T, Spaide RF. Prevalence and significance of subretinal drusenoid deposits (reticular pseudodrusen) in age-related macular degeneration. Ophthalmology 2010; 117(9): 1775-81.

[http://dx.doi.org/10.1016/j.ophtha.2010.01.027] [PMID: 20472293]

[93] Risk factors associated with age-related macular degeneration. A casecontrol study in the age-related eye disease study: Age-related eye disease study report number 3. Ophthalmology 2000; 107(12): 2224-32.

[PMID: 11097601]

[94] Bressler NM, Bressler SB, West SK, Fine SL, Taylor HR. The grading and prevalence of macular degeneration in Chesapeake Bay watermen. Arch Ophthalmol 1989; 107(6): 847-52.

[http://dx.doi.org/10.1001/archopht.1989.01070010869032] [PMID: 2786408]

[95] Ferris FL, Davis MD, Clemons TE, et al. A simplified severity scale for age-related macular degeneration: AREDS Report No. 18. Arch Ophthalmol 2005; 123(11): 1570-4.

[http://dx.doi.org/10.1001/archopht.123.11.1570] [PMID: 16286620]

[96] Ferris FL III, Wilkinson CP, Bird A, et al. Clinical classification of age-related macular degeneration. Ophthalmology 2013; 120(4): 844-51.

[http://dx.doi.org/10.1016/j.ophtha.2012.10.036] [PMID: 23332590]

[97] Klein R, Davis MD, Magli YL, Segal P, Klein BE, Hubbard L. The Wisconsin age-related maculopathy grading system. Ophthalmology 1991; 98(7): 1128-34

[http://dx.doi.org/10.1016/S0161-6420(91)32186-9] [PMID: 1843453]

[98] Mitchell P, Liew G, Gopinath B, Wong TY. Age-related macular degeneration. Lancet 2018; 392(10153): 1147-59.

[http://dx.doi.org/10.1016/S0140-6736(18)31550-2]

[PMID: 30303083]

[99] Spaide RF. Improiving the age related maculkar degeneration construcrt: a new classification system. Retina 2018; 38(5): 891-9. [http://dx.doi.org/10.1097/IAE.0000000000001732] [PMID 28557901]

[100] Olsen TW, Feng X. The minnesota grading system of eye bank eyes for age-related macular degeneration. Invest Ophthalmol Vis Sci 2004; 45(12): 4484-90.

[http://dx.doi.org/10.1167/iovs.04-0342] [PMID: 15557458]

\section{C) 2019 Salimiaghdam et al.}

This is an open access article distributed under the terms of the Creative Commons Attribution 4.0 International Public License (CC-BY 4.0), a copy of which is available at: https://creativecommons.org/licenses/by/4.0/legalcode. This license permits unrestricted use, distribution, and reproduction in any medium, provided the original author and source are credited. 